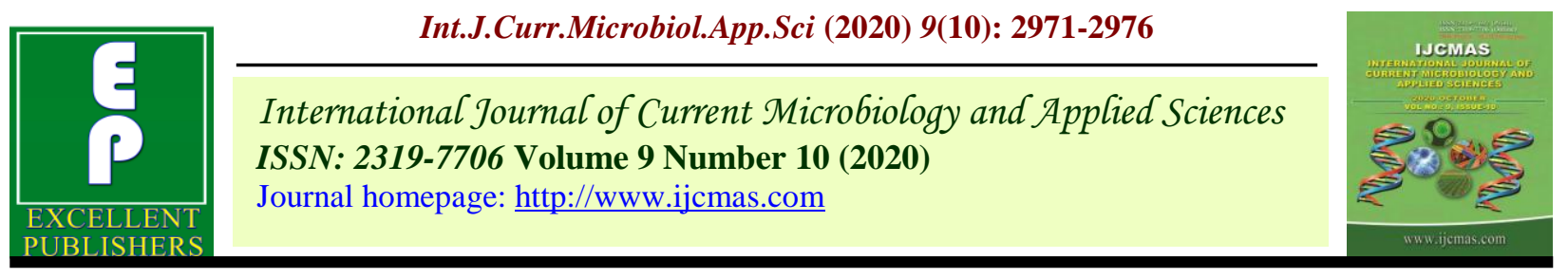

Original Research Article

https://doi.org/10.20546/ijcmas.2020.910.358

\title{
Productivity and Economics of Irrigated Wheat as Influenced by Nitrogen and Sulphur Levels
}

\author{
Zamir Muradi ${ }^{1 *}$ and T. Sudha ${ }^{2}$ \\ Department of Agronomy, College of Agriculture, UAS, Dharwad-580005, Karnataka, India \\ *Corresponding author
}

\section{A B S T R A C T}

\section{Keywords}

Wheat, Grain yield,

Economics,

sedimentation,

Nitrogen, Sulphur

Article Info

Accepted:

24 September 2020

Available Online:

10 October 2020
A field experiment was conducted at All India Co-ordinated Wheat and Barley Improvement Project (AICW \& BIP), Main Agricultural Research Station, UAS, Dharwad, to study the productivity and economics of irrigated wheat as influenced by nitrogen and sulphur levels. The field experiment was laid out in split-plot design with three replications and twelve treatment combinations involving three main and four subplots. The results indicated that, application of $125 \mathrm{~kg} \mathrm{~N} \mathrm{ha}^{-1}$ along with sulphur 30 $\mathrm{kg} \mathrm{ha}^{-1}$ has recorded significantly higher grain yield $\left(42.47 \mathrm{q} \mathrm{ha}^{-1}\right)$, gross return (Rs. $92.756 \mathrm{ha}^{-1}$ ), net return (Rs. $54064 \mathrm{ha}^{-1}$ ) and sedimentation value $(47.23 \mathrm{ml})$ and was on par with application of $100 \mathrm{~kg} \mathrm{~N} \mathrm{ha}^{-1}$ along with sulphur level @ $20 \mathrm{~kg} \mathrm{ha}^{-1}$. However, significantly lower grain yield (23.02 $\mathrm{q} \mathrm{ha}{ }^{-1}$ ), gross return (Rs. $51039 \mathrm{ha}^{-1}$ ), net return (Rs. $14228 \mathrm{ha}^{-1}$ ) and sedimentation value $(45.48 \mathrm{ml})$ were observed with application of nitrogen at $75 \mathrm{~kg} \mathrm{ha}^{-1}$ along with $0 \mathrm{~kg} \mathrm{Sha}^{-1}$.

\section{Introduction}

Wheat (Triticum aestivum L.) is the second most important cereal staple food crop and vital source of energy in human diet next to rice crop and which is contributing nearly 35 per cent to the national food basket. In India, wheat plays a significant role in food and nutritional security as it is an excellent health building staple food consumed by around 65 per cent of the population in various forms. In India, wheat is grown in an area of 30.59 million hectares ( $\mathrm{m}$ ha), with an annual production of about 98.51 million tonnes (m ton) and average productivity of about 3216 $\mathrm{kg} \mathrm{ha}{ }^{-1}$ (Anon., 2019). The productivity of wheat in Karnataka state is around $1075 \mathrm{~kg}$ $\mathrm{ha}^{-1}$ with an area of 1.68 lakh hectare with an annual production of 1.71 lakh tonnes (Anon., 2019).

The quantity of fertilizers applied depends on crop, inherent soil fertility status, yield goal and other considerations like irrigated or 
rainfed conditions. Optimal production requires suitable cultural practices including proper fertility management. Nitrogen is considered as one of the major nutrient for crop growth and development. The main function of nitrogen is part of proteins, phytohormones, coenzymes and chlorophyll formation and nucleic acid synthesis. All these biochemical activity involved in crop plants, are mainly responsible for nitrogen and other compounds which make it essential for crop growth and development of wheat (Kutman et al., 2011). Therefore, application of nitrogenous fertilizer at optimum dose is essential to soil to get higher productivity of wheat (Ali et al., 2000). The main significant role of sulphur in agriculture is gaining importance because of the recognition of its role in increasing crop production, not only in oilseeds, pulses and forages but also helpful for many cereal crops (Singh et al., 2000). Nowadays, sulphur deficiency occurring gradually due to continuous use of sulphur free fertilizers, high yielding varieties and intensive cropping system for higher productivity. It is noticed that optimum application of sulphur resulted in higher grain and straw yield of wheat (Yadav et al., 2017). The productivity of wheat is largely depends on its nutrient requirement and management particularly that of nitrogen, phosphorus, potassium and sulphur. Information on fertilizer requirement particularly nitrogen and sulphur levels on irrigated wheat is scanty. Hence, there is need to determine optimum levels of nitrogen and sulphur for growth, yield and economics of irrigated wheat in Northern Transition Zone of Karnataka.

\section{Materials and Methods}

The field experiment was conducted at University of Agricultural Sciences, Dharwad of Northern Transition Zone of Karnataka, during Rabi 2019. The field experiment was laid out in Split-plot design with three replications. There were 12 treatment combinations involving three main plots and four sub plots. Soil of the experimental site was neutral in reaction and soil differed in fertility status. The experimental site soil $\mathrm{pH}$ (7.52), electrical conductivity $\left(0.25 \mathrm{dS} \mathrm{m}^{-1}\right)$, organic carbon $(0.67 \%)$, available $\mathrm{N}(220 \mathrm{~kg}$ $\left.\mathrm{ha}^{-1}\right), \mathrm{P}_{2} \mathrm{O}_{5}\left(23.1 \mathrm{~kg} \mathrm{ha}^{-1}\right), \mathrm{K}_{2} \mathrm{O}\left(395.4 \mathrm{~kg} \mathrm{ha}^{-1}\right)$ and $\mathrm{S}(10.5 \mathrm{ppm})$. The treatments comprised of main plots: Nitrogen levels $\left(\mathrm{kg} \mathrm{ha}^{-1}\right) \mathrm{N}_{1}: 75$ $\mathrm{kg} \mathrm{ha}^{-1}, \mathrm{~N}_{2}: 100 \mathrm{~kg} \mathrm{ha}^{-1}$ and $\mathrm{N}_{3}: 125 \mathrm{~kg} \mathrm{ha}^{-1}$, Sub plots: Sulphur levels $\left(\mathrm{kg} \mathrm{ha}^{-1}\right) \mathrm{S}_{1}: 0 \mathrm{~S}_{2}: 10$ $\mathrm{kg} \mathrm{ha}^{-1} \mathrm{~S}_{3}: 20 \mathrm{~kg} \mathrm{ha}^{-1}$ and $\mathrm{S}_{4}: 30 \mathrm{~kg} \mathrm{ha}^{-1}$. The application of recommended dose of fertilizers $75 \mathrm{~kg} \mathrm{P}_{2} \mathrm{O}_{5}: 50 \mathrm{kgK}_{2} \mathrm{O} \mathrm{ha}^{-1}$ and FYM @ 7.5 tonnes ha ${ }^{-1}$ was common to all the treatments and sulphur was applied through gypsum. The test crop was irrigated wheat (UAS 304). The observation on grain and economics were recorded as per treatments accordingly.

\section{Results and Discussion}

Among the nitrogen levels, significantly higher plant height $(82.76 \mathrm{~cm})$, dry matter production (309.99 g), leaf area index (3.29) and effective tillers (273.83) were recorded with nitrogen level of $125 \mathrm{~kg} \mathrm{ha}^{-1}$, however, it was on par with $100 \mathrm{~kg} \mathrm{~N} \mathrm{ha}^{-1}$. Whereas, significantly lower growth parameters viz., plant height $(75.63 \mathrm{~cm})$, dry matter production (288.03 g), leaf area index (3.02) and effective tillers (254.25) ) were observed with nitrogen level of $75 \mathrm{~kg} \mathrm{ha}^{-1}$ The application of nitrogen at optimum level which might have helped in irrigated wheat plant to enhance the more number of leaves per plant and higher leaf area which helped in more photosynthetic activity, and thus contributed for higher dry matter accumulation at different parts of the irrigated wheat. The similar results are noticed by Ali et al., (2011), Ullah et al., (2018) and Yousaf et al., (2019). 
The investigation on sulphur levels revealed that significantly higher plant height $(83.60$ $\mathrm{cm})$, dry matter production (303.99 g), leaf area index (3.33) and effective tillers (278.33) were recorded (Table 1) with sulphur level of $30 \mathrm{~kg} \mathrm{ha}^{-1}$, however, it was on par with $20 \mathrm{~kg}$
$\mathrm{S} \mathrm{ha}{ }^{-1}$. Whereas, significantly lower growth parameters such as, plant height $(74.61 \mathrm{~cm})$, dry matter production $(284.70 \mathrm{~g})$, leaf area index (2.94) and effective tillers (247.77) were observed with sulphur level of 75 $\mathrm{kg} \mathrm{ha}^{-1}$.

Table.1 Growth parameters at harvest of irrigated wheat as influenced by nitrogen and sulphur levels

\begin{tabular}{|c|c|c|c|c|}
\hline \multirow[t]{2}{*}{ Treatments } & \multicolumn{4}{|c|}{ Growth parameters of irrigated wheat } \\
\hline & Plant height (cm) & $\begin{array}{c}\text { Dry matter } \\
\text { production (g) }\end{array}$ & Leaf area index & Effective tillers \\
\hline \multicolumn{5}{|c|}{ Main plots: Nitrogen levels $\left(\mathrm{kg} \mathrm{ha}^{-1}\right)$} \\
\hline$N_{1}: 75 \mathrm{~kg} \mathrm{ha}^{-1}$ & 75.63 & 288.03 & 3.02 & 254.25 \\
\hline $\mathrm{N}_{2}: 100 \mathrm{~kg} \mathrm{ha}^{-1}$ & 80.58 & 297.04 & 3.22 & 265.92 \\
\hline$N_{3}: 125 \mathrm{~kg} \mathrm{ha}^{-1}$ & 82.76 & 309.99 & 3.29 & 273.83 \\
\hline SE.m \pm & 0.99 & 3.92 & 0.05 & 4.01 \\
\hline C.D@ $5 \%$ & 3.90 & 15.39 & 0.18 & 15.74 \\
\hline \multicolumn{5}{|c|}{ Sub plots: Sulphur levels $\left(\mathrm{kg} \mathrm{ha}^{-1}\right)$} \\
\hline$S_{1}: 0$ & 74.61 & 284.70 & 2.94 & 247.77 \\
\hline$S_{2}: 10 \mathrm{~kg} \mathrm{ha}^{-1}$ & 78.50 & 293.58 & 3.20 & 262.78 \\
\hline$S_{3}: 20 \mathrm{~kg} \mathrm{ha}^{-1}$ & 81.91 & 303.99 & 3.24 & 269.78 \\
\hline$S_{4}: 30 \mathrm{~kg} \mathrm{ha}^{-1}$ & 83.60 & 311.14 & 3.33 & 278.33 \\
\hline SE.m \pm & 2.08 & 5.65 & 0.05 & 4.95 \\
\hline C.D @ $5 \%$ & 6.18 & 16.79 & 0.16 & 14.70 \\
\hline \multicolumn{5}{|l|}{ Interaction } \\
\hline $\mathbf{N}_{1} \mathbf{S}_{1}$ & 67.73 & 273.96 & 2.70 & 233.65 \\
\hline $\mathbf{N}_{1} \mathbf{S}_{2}$ & 72.63 & 281.10 & 3.01 & 249.67 \\
\hline $\mathbf{N}_{1} \mathbf{S}_{3}$ & 80.73 & 293.69 & 3.10 & 260.67 \\
\hline $\mathbf{N}_{1} \mathbf{S}_{4}$ & 81.43 & 303.36 & 3.29 & 273.00 \\
\hline $\mathbf{N}_{2} \mathbf{S}_{1}$ & 76.37 & 288.83 & 3.05 & 253.33 \\
\hline $\mathbf{N}_{2} \mathbf{S}_{2}$ & 80.93 & 294.65 & 3.25 & 261.67 \\
\hline $\mathbf{N}_{2} \mathbf{S}_{3}$ & 81.70 & 298.93 & 3.26 & 270.00 \\
\hline $\mathbf{N}_{2} \mathbf{S}_{4}$ & 83.30 & 305.74 & 3.33 & 278.67 \\
\hline $\mathbf{N}_{3} \mathbf{S}_{1}$ & 79.73 & 291.29 & 3.08 & 256.33 \\
\hline $\mathbf{N}_{3} \mathbf{S}_{2}$ & 81.93 & 305.00 & 3.33 & 277.00 \\
\hline $\mathbf{N}_{3} \mathbf{S}_{3}$ & 83.30 & 319.36 & 3.36 & 278.67 \\
\hline $\mathbf{N}_{3} \mathbf{S}_{4}$ & 86.07 & 324.33 & 3.36 & 283.33 \\
\hline SE.m \pm & 3.60 & 9.79 & 0.09 & 8.57 \\
\hline C.D @ 5 \% & NS & NS & NS & NS \\
\hline
\end{tabular}


Table.2 Grain yield, economics and quality of irrigated wheat as influenced by nitrogen and sulphur levels

\begin{tabular}{|c|c|c|c|c|c|}
\hline \multirow[t]{2}{*}{ Treatments } & \multicolumn{5}{|c|}{ Grain yield and Economics of irrigated wheat } \\
\hline & $\begin{array}{l}1000 \text { grain } \\
\text { weight (g) }\end{array}$ & $\begin{array}{c}\text { Grain yield } \\
\text { (q/ha) }\end{array}$ & $\begin{array}{l}\text { Gross return } \\
\quad\left(\text { Rs.ha }^{-1}\right)\end{array}$ & $\begin{array}{l}\text { Net return } \\
\left(\text { Rs.ha }^{-1}\right)\end{array}$ & $\begin{array}{l}\text { Sedimentation } \\
\text { values }(\mathbf{m l})\end{array}$ \\
\hline \multicolumn{6}{|c|}{ Main plots: Nitrogen levels $\left(\mathrm{kg} \mathrm{ha}^{-1}\right)$} \\
\hline $\mathrm{N}_{1}: 75 \mathrm{~kg} \mathrm{ha}^{-1}$ & 37.29 & 30.04 & 66387 & 29015 & 45.86 \\
\hline $\mathrm{N}_{2}: 100 \mathrm{~kg} \mathrm{ha}^{-1}$ & 38.26 & 35.11 & 77351 & 39601 & 46.08 \\
\hline$N_{3}: 125 \mathrm{~kg} \mathrm{ha}^{-1}$ & 38.87 & 39.22 & 85913 & 47785 & 46.69 \\
\hline SE.m \pm & 0.25 & 1.15 & 2440 & 2440 & 0.14 \\
\hline C.D@ $5 \%$ & 1.00 & 4.51 & 9582 & 9582 & 0.64 \\
\hline \multicolumn{6}{|c|}{ Sub plots: Sulphur levels $\left(\mathrm{kg} \mathrm{ha}^{-1}\right)$} \\
\hline $\mathbf{S}_{1}: 0$ & 36.88 & 28.49 & 62935 & 25736 & 45.16 \\
\hline$S_{2}: 10 \mathrm{~kg} \mathrm{ha}^{-1}$ & 37.93 & 33.37 & 73594 & 36036 & 46.10 \\
\hline $\mathrm{S}_{3}: 20 \mathrm{~kg} \mathrm{ha}^{-1}$ & 38.54 & 37.29 & 81933 & 43994 & 46.29 \\
\hline $\mathrm{S}_{4}: 30 \mathrm{~kg} \mathrm{ha}^{-1}$ & 39.20 & 40.01 & 87748 & 49434 & 46.92 \\
\hline SE.m \pm & 0.41 & 1.07 & 2172 & 2172 & 0.27 \\
\hline C.D @ $5 \%$ & 1.22 & 3.17 & 6454 & 6454 & 0.79 \\
\hline \multicolumn{6}{|l|}{ Interaction } \\
\hline $\mathbf{N}_{1} \mathbf{S}_{1}$ & 35.44 & 23.02 & 51039 & 14228 & 45.48 \\
\hline $\mathbf{N}_{1} \mathbf{S}_{2}$ & 37.17 & 26.90 & 59534 & 22354 & 45.60 \\
\hline $\mathbf{N}_{1} \mathbf{S}_{3}$ & 38.10 & 33.50 & 73918 & 36357 & 45.70 \\
\hline $\mathbf{N}_{1} \mathbf{S}_{4}$ & 38.47 & 36.73 & 81057 & 43121 & 46.68 \\
\hline $\mathbf{N}_{2} \mathbf{S}_{1}$ & 37.30 & 29.10 & 64435 & 27246 & 45.28 \\
\hline $\mathbf{N}_{2} \mathbf{S}_{2}$ & 38.20 & 34.21 & 75536 & 37978 & 45.87 \\
\hline $\mathbf{N}_{2} \mathbf{S}_{3}$ & 38.37 & 36.31 & 80004 & 42065 & 46.06 \\
\hline $\mathbf{N}_{2} \mathbf{S}_{4}$ & 39.17 & 40.84 & 89431 & 51117 & 46.86 \\
\hline $\mathbf{N}_{3} \mathbf{S}_{1}$ & 37.90 & 33.35 & 73302 & 35735 & 45.61 \\
\hline $\mathbf{N}_{3} \mathbf{S}_{2}$ & 38.43 & 38.99 & 85712 & 47776 & 46.82 \\
\hline $\mathbf{N}_{3} \mathbf{S}_{3}$ & 39.17 & 42.07 & 91879 & 53562 & 47.10 \\
\hline $\mathbf{N}_{3} \mathbf{S}_{4}$ & 39.97 & 42.47 & 92756 & 54064 & 47.23 \\
\hline SE.m \pm & 0.71 & 1.85 & 3762 & 3762 & 0.48 \\
\hline C.D @ $5 \%$ & NS & 5.49 & NS & NS & NS \\
\hline
\end{tabular}


The higher growth parameters might be due to higher sulphur application which enhanced physiological activity in the plant, chlorophyll formation and ultimately enhanced the higher dry matter production in different parts of the plant. The similar findings were noticed by Ponkia et al., (2018) in wheat.

Among the sulphur levels, grain yield, economics and quality of irrigated wheat differed significantly. Significantly higher 1000 grain weight $(39.20 \mathrm{~g})$, grain yield (40.01 q ha ${ }^{-1}$ ), gross return (Rs. $87748 \mathrm{ha}^{-1}$ ), net return (Rs. $49434 \mathrm{ha}^{-1}$ ) and sedimentation value $(46.92 \mathrm{ml})$ were recorded with sulphur level of $30 \mathrm{~kg} \mathrm{ha}^{-1}$. However, it was on par with $20 \mathrm{~kg} \mathrm{~S} \mathrm{ha}{ }^{-1}$. Whereas, significantly lower 1000 grain weight (36.88 g) grain yield (28.49 q ha ${ }^{-1}$ ), gross return (Rs. $62935 \mathrm{ha}^{-1}$ ), net return (Rs. $25736 \mathrm{ha}^{-1}$ ) and sedimentation value $(45.16 \mathrm{ml})$ was observed with 0 $\mathrm{kg} \mathrm{S} \mathrm{ha-1} \mathrm{(Table} \mathrm{2).} \mathrm{The} \mathrm{sulphur} \mathrm{helped} \mathrm{the}$ plant to perform physiological activity like synthesis of sulphur containing amino acids such as, cysteine, cystine and methionine and involved in various metabolic processes of plant and constituent of glutathione, a compound associated with the plant respiration, synthesis of essential oil and formation of chlorophyll. The application of sulphur resulted in enhanced availability of nitrogen and higher uptake by crop. These similar findings are close confirmed by Metha et al., (2005), Yadav et al., (2017) and Ponkia et al., (2018).

The application of $125 \mathrm{~kg} \mathrm{~N} \mathrm{ha}^{-1}$ along with sulphur $30 \mathrm{~kg} \mathrm{ha}^{-1}$ recorded significantly higher grain yield ( $\left.42.47 \mathrm{q} \mathrm{ha}^{-1}\right)$, gross return (Rs. $92.756 \mathrm{ha}^{-1}$ ) and net return (Rs. 54064 ha $\left.{ }^{1}\right)$ which was on par with $100 \mathrm{~kg} \mathrm{~N} \mathrm{ha}^{-1}$ along with sulphur level@20 kg ha- ${ }^{-1}$. However, significantly lower grain yield (23.02 q ha $\left.{ }^{-1}\right)$, gross return (Rs. $51039 \mathrm{ha}^{-1}$ ) and net return (Rs. $14228 \mathrm{ha}^{-1}$ ) were observed with nitrogen level $75 \mathrm{~kg} \mathrm{ha}^{-1}$ along with $0 \mathrm{~kg} \mathrm{~S} \mathrm{ha}^{-1}$. The higher grain yield might be due to interaction effect of nitrogen and sulphur levels which ultimately enhanced yield of irrigated wheat (Dostalova et al., 2015). The synergetic effect between potassium and sulphur levels helped in increasing the grain and straw yield to the extent of 38.0 and 36.6 per cent with application of $60 \mathrm{~kg} \mathrm{~K}_{2} \mathrm{O} \mathrm{ha}^{-1}$ and along with $40 \mathrm{~kg} \mathrm{~S} \mathrm{ha}{ }^{-1}$ over control (Ponkia et al., 2018).

In conclusion, treatment combination of 125 $\mathrm{kg} \mathrm{N} \mathrm{ha}{ }^{-1}$ along with sulphur $30 \mathrm{~kg} \mathrm{ha}^{-1}$ resulted in significantly higher growth parameters, grain yield and economics of irrigated wheat which was on par with application of $100 \mathrm{~kg} \mathrm{~N}^{-1}$ along with sulphurlevel @20 kg ha-1.

\section{Acknowledgement}

I would like to thank Indian Council of Agricultural Research (ICAR) Department of Research and Education (DARE), New Delhi under India-Afghanistan Fellowship program and University of Agricultural Science, Dharwad for all their help, efforts and support throughout the completion of my degree programme.

\section{References}

Ali, A., Ahmad, A., Syed, W. H., Khaliq, T. and Ali, P., 2011, Effects of nitrogen on growth and yield components of wheat. Sci. Inter., 24:331-332.

Anonymous, 2019, Area, production and productivity of wheat in India and Karnataka. www.Indiastat.com.

Dostalova, Y., Hrivna, L., B. Kotkova, B. and V. Sottnikova, V., 2015, Effect of nitrogen and sulphur fertilization on the quality of barley protein. Plant Soil Environ., 61(9): 399-404.

Kutman, U. B., Yildiz, B. and Cakmak, I., 2011, Effect of nitrogen on uptake, 
remobilization and partitioning of zinc and iron throughout the development of durum wheat. Plant Soil., 342: 149-164.

Lakho, A. A., Oad, F. C., Samo, H. A. and Ghaloo, S. H., 2004, Economic analysis of wheat under different nitrogen levels and placements. Asian J. Plant Sci., 3: 69-71.

Metha, 2005, Importance of sulphur nutrition to crops. Agro bios., Pp. 21-25.

Ponkia, H. P., Vekaria, L. C., Ramani, V. B. and Sakrvadia, H. L., 2018, Potassium and sulphur fertilization of wheat (Triticum aestivum L.) in medium black calcareous soils of Saurashtra Region of Gujarat. Int. J. Pure App. Biosci., 6 (1): 1634-1640.

Ullah, M., Ali, N., Durrani, S., Muhammad
A., Abdul, H. and Hafeez A., 2018, Effect of different nitrogen levels on growth, yield and yield contributing attributes of wheat. International J. Sci. Engineering Res., 9(9): 201-205.

Yadav, S. K., Singh, G., Kumar, R. and Pradeep Kumar., 2017, Effect of phosphorus, sulphur and zinc on growth, yield and yield attributes of wheat (Triticum aestivum) Int. J. Curr. Microbiol. App. Sci., 6(8): 2581-2584.

Yousaf, M., Muhammad S., Suliman, A. and Ali, M., 2019, The effect of nitrogen application rates and timings of first irrigation on wheat growth and yield. International J. Agric. Inno. Res., 2(4): $120-125$.

\section{How to cite this article:}

Zamir Muradi and Sudha, T. 2020. Productivity and Economics of Irrigated Wheat as Influenced by Nitrogen and Sulphur Levels. Int.J.Curr.Microbiol.App.Sci. 9(10): 2971-2976. doi: https://doi.org/10.20546/ijcmas.2020.910.358 